\title{
Geoffrey and Gender: the Works of Geoffrey of Monmouth as Medieval "Feminism"
}

\author{
Fiona Tolhurst
}

Readers of the extant works of Geoffrey of Monmouth will not be surprised to find a chapter on Geoffrey and gender issues in this volume, for the work in feminist theory produced during the 198 os and 1990s made such a strong case for the relevance and usefulness of feminist approaches to medieval texts that feminist interpretations are now part of the critical mainstream in medieval studies. ${ }^{1}$ However, postcolonialist work on Geoffrey's oeuvre has tended to overshadow feminist work on it. ${ }^{2}$ A possible explanation of this pattern is

1 See, for example, J.M. Bennett, Ale, Beer, and Brewsters in England: Women's Work in a Changing World, 1300-1600, Oxford, 1996; E.J. Burns, Bodytalk: When Women Speak in Old French Literature, Philadelphia, 1993; C.W. Bynum, Jesus as Mother: Studies in the Spirituality of the High Middle Ages, Berkeley, 1982; S. Delany, “'Mothers to Think Back Through': Who Are They? The Ambiguous Example of Christine de Pizan", in L.A. Finke and M.B. Shichtman (eds.), Medieval Texts \& Contemporary Readers, Ithaca, 1987, pp. 177-97; C. Dinshaw, Chaucer's Sexual Poetics, Madison, 1989; L. Finke, "The Rhetoric of Marginality: Why I Do Feminist Theory", Tulsa Studies in Women's Literature 5:2 (1986), 251-72; B.A. Hanawalt, "Of Good and Ill Repute": Gender and Social Control in Medieval England, Oxford, 1998; R.L. Krueger, Women Readers and the Ideology of Gender in Old French Verse Romance, Cambridge, 1993; K. Lochrie, Margery Kempe and Translations of the Flesh, Philadelphia, 1991; and L. Lomperis and S. Stanbury (eds.), Feminist Approaches to the Body in Medieval Literature, Philadelphia, 1993. For retrospectives on feminist work in medieval studies, see J.M. Bennett, "Medievalism and Feminism", Speculum 68:2 (1993), 309-31; C. Dinshaw, "Medieval Feminist Criticism", in G. Plain and S. Sellers (eds.), A History of Feminist Literary Criticism, Cambridge, 2007, pp.11-26; E. Robertson, "Medieval Feminism in Middle English Studies: A Retrospective”, Tulsa Studies in Women's Literature 26:1 (2007), 67-79; and N.N. Sidhu, "Love in a Cold Climate: The Future of Feminism and Gender Studies in Middle English Scholarship", Literature Compass 6:4 (2009), 864-85.

2 Postcolonialist interpretations of Geoffrey's works include C. Chism, “'Ain't gonna study war no more': Geoffrey of Monmouth's Historia regum Britanniae and Vita Merlini", The Chaucer Review 48:4 (2014), 458-79; J.J. Cohen, Of Giants: Sex, Monsters, and the Middle Ages (Medieval Cultures, 17), Minneapolis, 1999, pp. 29-61; M.A. Faletra, Wales and the Medieval Colonial Imagination: The Matters of Britain in the Twelfth Century, New York, 2014, pp. 19-54; L.A. Finke \& M.B. Shichtman, King Arthur and the Myth of History, Gainesville, 2004, 
that much of the best work in Galfridian studies has combined postcolonialist and feminist methodologies. ${ }^{3}$ The only book-length studies to focus solely on Geoffrey's unusually flexible conception of gender roles in his Prophetiae Merlini, De gestis Britonum, and Vita Merlini are my own. ${ }^{4}$ Nevertheless, a historicist-feminist approach provides a useful vantage point from which to analyze Geoffrey's extant works because he completed his history in late 1138 - the historical moment at which Empress Matilda was preparing for her September 1139 military campaign to take the English throne from her usurping cousin Stephen of Blois. ${ }^{5}$ Historicist-feminist analysis confirms what J.S.P. Tatlock asserted in 1938: that Geoffrey's creation of several female rulers of early Britain in the $D G B$ constituted support for Empress Matilda's claim to the English throne, a claim based on hereditary right through her father King Henry I. ${ }^{6}$

However, this type of analysis also reveals that Geoffrey's extant works require two modifications to Maureen Fries' categories for female characters in the Arthurian tradition: female counter-heroes, heroines, and female heroes. ${ }^{7}$ Although the categories of female counter-hero (a character who often acts out of self-interest and rejects traditional female roles that support male endeavors) and heroine (a passive figure who inspires and rewards the actions of knights) are useful, Fries' definition of the female hero as deliberately playing female roles to transform her "male-dominant world" while always benefitting knights does not encompass the variety of heroisms that Galfridian females embody. ${ }^{8}$ Therefore, scholars must broaden Fries' definition to include females

pp. 35-70; P.C. Ingham, Sovereign Fantasies: Arthurian Romance and the Making of Britain, Philadelphia, 2001, pp. 21-50; and M.R. Warren, History on the Edge: Excalibur and the Borders of Britain, 1100-1300 (Medieval Cultures, 22), Minneapolis, 2000, pp. 25-59.

3 Interpretations of Geoffrey's works that combine postcolonialist and feminist methodologies include Chism, “'Ain't gonna study war no more', pp. 458-79; Cohen, Of Giants, pp. 29-61; Finke and Shichtman, Myth of History, pp. 35-70; and Warren, History on the Edge, pp. 25-59.

4 F. Tolhurst, Geoffrey of Monmouth and the Feminist Origins of the Arthurian Legend, New York, 2012; ead., Geoffrey of Monmouth and the Translation of Female Kingship, New York, 2013.

5 Geoffrey's history was completed by January 1139 when fellow historian Henry of Huntingdon learned of its existence, and both historian Neil Wright and editor of the $D G B$ Michael Reeve argue for a date shortly before January 1139 - making late 1138 the most accurate estimate. Bern, ed. Wright, p. xvi; M.D. Reeve, "The Transmission of the Historia regum Britanniae", Journal of Medieval Latin 1 (1991), 73-117, at p. 73 .

6 J.S.P. Tatlock, "Geoffrey of Monmouth's Motives for Writing His Historia", Proceedings of the American Philosophical Society 79:4 (1938), 695-703, at pp. 695 and 701-02.

7 M. Fries, "Female Heroes, Heroines and Counter-Heroes: Images of Women in Arthurian Tradition", in S.K. Slocum (ed.), Popular Arthurian Traditions, Bowling Green, OH, 1992, pp. $5^{-17}$.

8 Fries, "Female Heroes", p. 15. 
who take on at least some of the characteristics of a male hero, such as protecting another, weaker character. Scholars must also add the category of female king: a woman who, unlike a queen consort, wields political power independent of male influence.

The varied, complex, and predominantly positive images of women Geoffrey creates in all three of his extant works distinguish him from most male authors of the Middle Ages and support the claim that he is a "feminist" for his time, if readers define "feminist" in a period-specific sense: his works depart from, and implicitly reject, the antifeminist tradition of the Middle Ages. Admittedly, this definition of "feminist" is limited (even conservative by modern standards), yet it is appropriate within a 12th-century cultural context: neither Geoffrey of Monmouth - a man embedded in and trying to benefit from the male-dominated power structures of the Anglo-Normans - nor his fellow 12thcentury clerics seeking the patronage of powerful nobles would have had any reason to call for fundamental changes to those power structures. Nevertheless, as L.A. Finke and M.B. Shichtman have noted, Geoffrey's work differs from that of other medieval historians in its "feminist" inclusiveness: "Geoffrey's Historia seems unable not to mention women. It is populated by all sorts of women, whose stories weave their way through the battles, trades, and negotiations" (my emphasis). ${ }^{9}$ As I have argued elsewhere, Geoffrey's choice to include in his history women who play roles other than those of saint, loyal wife, nurturing mother, and temptress sets him apart from his predecessors, contemporaries, and successors in Insular historiography, but his choice to do so in all three of his extant works makes him worthy of the title of "feminist" in the sense of working against the antifeminist mainstream of medieval historiography. ${ }^{10}$ In Geoffrey's $P M, D G B$, and $V M$, female figures not only play pivotal roles but also perform actions that do the "feminist" work of providing implicit critiques of the brutality, warmongering, moral weakness, and immorality that tend to characterize powerful males in the Galfridian world.

Geoffrey of Monmouth's $P M$ circulated separately from his history and had significant cultural power, both as a sacred text among scholars who redacted it in Latin and translated it into French, and as a literary text that might have

$9 \quad$ Finke and Shichtman, Myth of History, p. 55.

10 Tolhurst, Translation of Female Kingship, pp. 73-81, 133-259; ead., Feminist Origins, pp. 113-40. 
been responsible for popularizing prophetic literature in England. ${ }^{11}$ Within the $D G B$, however, these prophecies appear at the midpoint of Geoffrey's history and constitute a lengthy digression from his account of the reigns of more than 100 rulers of early Britain. This digression's position in the history invites readers to link it to both other sections of the book and events in Anglo-Norman history. Because Geoffrey's prophecies are expressed in obscure language and become increasingly opaque as the $P M$ section moves toward its conclusion, scholarly speculation about what the various animals might represent tends to overshadow examination of how the text presents two intriguing departures from traditional gender roles: Empress Matilda as rightful heir to the English throne, and two unnamed female figures as healers of harms that males have either failed to remove or somehow caused.

The $P M$ section injects the fantastic into a narrative dominated by military struggles for political power, yet it is like the rest of the non-Arthurian material in Geoffrey's history in agenda: it invokes Anglo-Norman anxieties about the issue of succession to the English throne, while presenting female figures as much-needed correctives to the foolish and destructive actions of males. Although readers today find Geoffrey's prophecies both vague and difficult to understand, it is likely that his contemporaries in the political know would have had the cultural context necessary to understand his use of various figures and events as coded references to the conflict between Empress Matilda and King Stephen, a conflict that would erupt into civil war in September of 1139 . Within the context of the $P M$ 's opening passage that contrasts the red dragon representing the Britons with the white dragon representing the Saxons, and Geoffrey's anti-civil-war diatribe that mentions a lioness and her cubs, Anglo-Norman readers might well have interpreted this statement as referring to the Empress: "The white dragon will rise in revolt again and summon/invite the daughter of Germany."12 Certainly, readers today might wonder whether "the daughter of Germany" might refer to a people or an army rather than a female person; however, the $P M$ 's references to sons and daughters seem to refer to gendered people, so there is no reason not to assume that this "daughter"

$11 D G B$, vii.109.1-7 and Reeve, "Transmission", pp. 94-97; J. Crick, "Geoffrey of Monmouth, Prophecy and History", Journal of Medieval History 18:4 (1992), 357-71, at p. 36o, n. 13; "Anglo-Norman Verse Prophecies of Merlin", ed. and trans. J. Blacker, Arthuriana 15:1 (2005), 1-125, at p. 10; A.F. Sutton and L. Visser-Fuchs, "The Dark Dragon of the Normans: A Creation of Geoffrey of Monmouth, Stephen of Rouen, and Merlin Silvester", Quondam et Futurus: A Journal of Arthurian Interpretations 2:2 (1992), 1-19, at p. 2.

$12 \quad D G B$, vii.112.34-38, xi.185.141-186.154, vii.112.63: "Exurget iterum albus draco et filiam Germaniae inuitabit." Translations from Geoffrey's $D G B$ and $V M$ are my own. For more on the $P M$, see Maud Burnett McInerney's contribution to this volume. 
refers to a female person - although which female person is open to debate. Furthermore, an Anglo-Norman audience familiar with King Henry I's attempt to ensure that his daughter Matilda would succeed him by requiring his barons to swear fealty to her at two public oathtakings likely saw in this prophecy a suggestion about Matilda: that she was invited, even summoned, by "the white dragon" to leave her home in the German-speaking Holy Roman Empire and rule the disordered island of Britain. ${ }^{13}$ Despite the fact that no historiographical text with which I am familiar labels either the Norman or the Frankish ancestors of Matilda and her cousin Stephen as "Germanici", the referent for the white dragon, that in the opening lines of the $P M$ is the Saxons, suddenly seems to become the Anglo-Normans. A possible explanation for this odd shift in referent is Geoffrey's desire to produce for the Anglo-Normans "a history that elided, as much as possible, the conflicted relationships among the five populis" in Britain (the Normans, Britons, Saxons, Scots, and Picts). ${ }^{14}$ This desire might have caused Geoffrey to conflate one Germanic bloodline (the Saxon) with other ones connected with Empress Matilda: she was born to a mother of English lineage and a father of Frankish lineage, and she became the wife of the German-speaking Emperor Henry v. If Geoffrey's Anglo-Norman audience did connect Merlin's prophecy about "Germans" with their own present, then Empress Matilda would have emerged for them as a better king-candidate than Stephen. The prophet says first that "the German worm will be crowned" and then that "the German dragon will barely maintain his caves because vengeance will be visited upon treason."15 Geoffrey's contemporaries would have found it easy to interpret these statements as applying to King Stephen, for he had committed treason - in "worm"-like fashion - by failing to honor his oath of fealty to his cousin, and then suffered what they might have construed as God's vengeance: Stephen struggled to retain the throne he had usurped. The contrast between dragon and worm could even be Geoffrey's playful way of encoding Stephen's dishonesty and moral weakness. Orderic Vitalis's oftencited identification of the leo iusticiae, "lion of justice", of Merlin's prophecies

13 William of Malmesbury, The Contemporary History i.2, i.8, ed. E. King, trans. K.R. Potter, William of Malmesbury. Historia novella: The Contemporary History, Oxford, 1998, pp. 6-7, 18-21; C. Beem, The Lioness Roared: The Problems of Female Rule in English History, New York, 2006, p. 26. Although the "Holy" part of the term Sacrum Romanum Imperium, "Holy Roman Empire", did not come into use until 1157 and is not attested until 1254, I follow the convention of using the term "Holy Roman Empire" to refer to the medieval Roman empire from the time of Otto I in 962 until that of Francis II in 1806.

$14 D G B$ i.5.42-44; Finke and Shichtman, Myth of History, p. 54.

$15 D G B$, vii.112.65, vii.113.69-71: "coronabitur Germanicus uermis", "Vix obtinebit cauernas suas Germanicus draco, quia ultio prodicionis eius superueniet." 
with Henry I not only sharpens the contrast between the morally questionable Stephen and the admirable figures of Empress Matilda and her father but also causes other references in the $P M$ to take on political meaning. ${ }^{16}$

Having referenced the 1120 drowning of three of King Henry I's children (the event that made Matilda her father's only surviving legitimate heir) by noting that " $t]$ he cubs of the lion were transformed into fish of the ocean", Merlin makes two comments about an eagle that, for Anglo-Norman elites, could have functioned as coded references to the Empress. ${ }^{17}$ The first eagle reference is gendered feminine, both by virtue of the feminine noun aquila, "eagle", and by the bird's activity of nesting that Anglo-Norman readers would likely have associated with a mother bird's caring for her young within the nest. Because this reference immediately follows the mention of the cubs' transformation into fish, it suggests that the dead King Henry's wishes will triumph: "and his eagle will build a nest on Mount Aravius." ${ }^{18}$ Anglo-Norman readers who identified this mount with Snowdon in Wales might have viewed the nest as signifying Matilda's potential base of military operations in Wales - where her halfbrother Robert of Gloucester, who later led Matilda's troops, held Glamorgan. ${ }^{19}$ Amid references to tears soaking the island nightly, Stephen's and Matilda's factions behaving badly, and Scotland rising up in anger, the second reference to the eagle seems to flatter Matilda: "The eagle of the broken pact will gild it [the bridle] and will delight in a third nesting." ${ }^{20}$ If 12 th-century readers assumed that the "broken pact" referred to the oaths that both Stephen and many Anglo-Norman barons had made to the Empress but failed to honor, then they might well have interpreted the bridle as the monarchial power that Matilda would make golden or perfect when she attained - through her birthright - her third "nesting" ( or site of power), England, having already attained power in the Holy Roman Empire through her first husband and power over Anjou through her second. To represent Matilda as an eagle would likely have seemed both entirely appropriate and symbolically logical to an Anglo-Norman audience, given both the Empress's status as a noblewoman and her title of Empress of

$16 \quad D G B$, vii.113.78; Orderic Vitalis, Ecclesiastical History xii.47 (iv.49o-94), ed. and trans. M. Chibnall, The Ecclesiastical History of Orderic Vitalis, 6 vols., Oxford, 1969-8o, vol. 6, pp. 384-89.

$17 D G B$, vii.113.84-85: "Catuli leonis in aequoreos pisces transformabuntur."

$18 D G B$, vii.113.85-86: "et aquila eius super montem Arauium nidificabit."

19 G. Heng discusses Mount Aravius as Snowdon in "Cannibalism, the First Crusade, and the Genesis of Medieval Romance", Differences: A Journal of Feminist Cultural Studies 10:1 (1998), 98-174, at pp. 118-19.

$20 \quad D G B$, vii.113.87-114.94: "Deaurabit illud aquila rupti foederis et tercia nidificatione gaudebit." 
the Romans; Geoffrey's doing so also contrasts her with Stephen as dragon/ worm. ${ }^{21}$ It is significant that Merlin's prophecies descend into obscurity after this sequence of events. The fact that symbolic representation of Matilda's future reign appears at the narrative moment at which the past becomes the present gives her a pivotal position in Geoffrey's construction of history.

Reinforcing the positive presentation of Empress Matilda in the $P M$, one unnamed female figure eliminates harms that males cannot remove, and another heals the harms that males somehow cause. The first one is a puella, "girl", who performs a rescuer's task that no male in the $P M$ appears able to perform. After an unidentified "they" (which presumably includes or consists mainly of males) fails to hide a spring that causes sudden death and makes the burial of its victims impossible, and this "they" likewise fails to contain another spring whose water causes those who drink it to die of unquenchable thirst, this girl "will bring in/use a cure of healing". ${ }^{22}$ Using "only her breath", she "will dry up the deadly springs". ${ }^{23}$ Then her evidently magical "sulphurous footsteps" will produce smoke that "will provide food for underwater creatures". ${ }^{24}$ Merlin's prophecy presents this girl as a healer who possesses powers that surpass those of males: she both prevents human deaths and supports animal life. The second female healer undoes the harms to Britain that males somehow cause. After a snake associated with a colonus Albaniae, "farmer of Scotland", destroys the harvest with its poison and causes the people in several cities to die, the city of Claudius sends the remedium, "remedy": alumpnam flagellantis, "the scourge's pupil or foster-daughter", who heals these harms to the natural world and its human inhabitants. ${ }^{25}$ Whether this scourge is the farmer associated with the snake, or a different male who is this female figure's teacher or fosterfather, Merlin's prophecy about her is clear: "She will carry the right balance ... of medicine, and in a short time the island will be restored." ${ }^{26}$ Given this female healer's connection with the city of Claudius, she could be Gewissa in the $D G B$, who ends the conflict between her father and husband; therefore, Merlin's prophecy suggests that women supply the medicine of peace. ${ }^{27}$

21 M.J. Curley notes that the eagle and dragon both "stood for Roman civilization itself" in "Animal Symbolism in the Prophecies of Merlin", in W.B. Clark and M.T. McMunn (eds.), Beasts and Birds of the Middle Ages: The Bestiary and Its Legacy, Philadelphia, 1989, pp. $151-63$, at p. 16 o.

$D G B$, vii.116.147-56: "medelae curam adhibeat".

$23 D G B$, vii.116.157: "solo anhelitu suo", "fontes nociuos siccabit".

$24 D G B$, vii.116.16o-61: "passus sulphureos", "cibum submarinis conficiet".

$25 \quad D G B$, vii..116.266-70.

$26 \quad D G B$, vii.116.270-71: "Stateram ... medicinae gestabit et in breui renouabitur insula."

$27 \quad D G B$, iiii.69.357-59. 
Although Geoffrey's $P M$ is a text with an apocalyptic ending, its references to the eagle associate Empress Matilda with the healing of Britain from the harm King Stephen has done to it. Similarly, its references to two young women associate womankind with healing Britain. Within the context of Geoffrey's diatribe about the horrors of civil war that enables him to speak in his own voice after Arthur's mortal wounding, the cataclysmic end of the world that Merlin prophesies provides a convincing demonstration of the destruction that civil war causes and the need for constructive female power. ${ }^{28}$

\section{De gestis Britonum: Female Regency and Kingship as Correctives to} Male Misbehavior

As noted above, the main plot of the $D G B$ articulates Geoffrey of Monmouth's anti-civil-war stance more directly than the $P M$. However, as the $D G B$ develops an account of the reigns of the more than 100 kings of Britain who ruled before the English gained dominion over the island, it also creates a sharper contrast between destructive male power and constructive female power. Within his narrative of early British kingship, Geoffrey reveals his "feminist" philosophy that the legitimate heir should reign - regardless of gender. He does so by including two female king-candidates who could have reigned, a female regent who admirably performs the military and political functions of a king, and two competent and moral female kings who do reign, both peacefully and successfully. Furthermore, the good qualities of the female regent and kings highlight the misconduct of male kings, misconduct that can indicate incompetence or criminality.

According to Geoffrey's version of the British past, both Helena the daughter of King Coel and the unnamed daughter of King Octavius could have - and should have - reigned as kings. Helena has the same problem that Empress Matilda had: due to her father's death, she must rely on noblemen to support her as a king-candidate. Like King Henry I, King Coel dies suddenly, leaving behind as his heir a daughter whom her father has educated so that she can rule facilius, "more easily", after his death. ${ }^{29}$ This description suggests that, like Henry who made clear his intention that his daughter would reign after

$28 \quad D G B$, xi.185.141-186.154.

$29 D G B$, v.78.140-42. For evidence of Matilda's preparation to rule well, see Beem, The Lioness Roared, pp. 35, 39-41 (political experience) and E. van Houts, "Latin and French as Languages of the Past in Normandy During the Reign of Henry II: Robert of Torigni, Stephen of Rouen, and Wace", in R. Kennedy and S. Meecham-Jones (eds.), Writers of the Reign of Henry II: Twelve Essays, New York, 2006, pp. 53-77, at pp. 66-69 (literacy in French, German, Latin, and possibly Italian). 
him by having his barons twice swear fealty to her, Coel intends for his daughter to reign. Geoffrey even underscores Helena's right to rule by having Duke Caradocus of Cornwall refer to Coel's daughter as "Helena [whom] we cannot deny is master of this kingdom by hereditary right". ${ }^{30}$ Helena does not reign, however, because Constantius takes the throne and marries her, begetting Constantinus upon her; for Helena, marriage denies her access to the political power her father had wanted her to have and transforms her into a receptacle for her husband's seed. The story of Octavius's daughter demonstrates that failure to support the legitimate female heir on the part of the king and his counselors results in civil war and all the unnecessary suffering it brings. First Octavius's nephew, Conanus Meriadocus, fights for the throne after Octavius gives his daughter and crown to a Roman nobleman named Maximianus; then, Conanus and Maximianus fight a series of battles in which each man causes dampnum maximum, "the greatest damage", to the other. ${ }^{31}$ When Maximianus finally acquires the throne, he not only displays saeuitia, "savagery", by slaughtering the French, but also leaves Britain open to attack by the Huns and Picts, for he has stripped Britain of much-needed defenders. ${ }^{32}$ These king-candidates matter in part because of precedents for female rule that Guendoloena, Cordeilla, and Marcia provide.

The story of Guendoloena, the first of Geoffrey's female figures who functions as a king, is striking for three reasons: it shows that a woman can be a more moral and more competent ruler than a man, it emphasizes her kingly functions rather than the fact that she chooses to step aside so that her son can rule, and it reveals Geoffrey's tendency not to villainize a female figure even when she commits a morally questionable act. In contrast to her husband Locrinus, who violates his marriage vows through a secret seven-year affair with his German mistress Estrildis, impregnates this mistress, and then tries to cast his lawful wife aside, Guendoloena fulfills her duties as queen consort: she remains faithful to her husband and gives birth to a male heir to the throne. ${ }^{33}$ Despite exchanging the traditional gender role of queen consort for leader of troops, Guendoloena receives the support of all of the young men of Cornwall (her home region) - a detail that underscores the justice of her cause and makes her a moral reformer rather than a rebel. ${ }^{34}$ This female leader then proves her moral superiority by becoming the apparent beneficiary of

$30 \quad D G B$, v.83.291-93: "Helenam nequimus abnegare hereditario iure regnum istud possidere".

$31 \quad D G B, v .81 .208-83 \cdot 305$.

$3^{2} \quad D G B, v .85 .331-86.359$, v.88.395-405.

$33 \quad D G B$, ii.24.4O-25.53.

$34 D G B$, ii.25.53-55; K. Olson interprets Guendoloena as an invader in "Gwendolyn and Estrildis: Invading Queens in British Historiography”, Medieval Feminist Forum 44:1 (2008), $3^{6-52 .}$ 
God's support when, on the battlefield, her husband dies after being struck by an arrow as he leads troops against Guendoloena's army. ${ }^{35}$ For Anglo-Norman readers who noted the similarity between Locrinus's death and that of King Harold II, who reputedly died after being wounded in the eye by an arrow during the Battle of Hastings, Guendoloena would become the "Norman" (rightful) king and Locrinus the "Saxon" (illegitimate) one who loses his throne to the leader whom God has chosen to rule Britain. Geoffrey's narration emphasizes that Guendoloena performs all of the functions of a king: she gathers and leads troops, defeats her enemy in battle, and eliminates those who pose a political threat to the rightful succession of her son Maddan by having her husband's mistress and illegitimate daughter executed. ${ }^{36}$ In a book containing many brief reigns, Guendoloena's fifteen-year reign - after her husband's ten-year one - underscores her competence to rule. ${ }^{37}$ Geoffrey's emphasis on Guendoloena's kingly functions rather than her status as a regent continues when he describes how she chooses to transfer power to her son Maddan once he is aetate adultum, "mature in age"; after her son reaches his majority and she steps aside so that he can rule, she then reigns alone over Cornwall - the region from which Galfridian Britain draws many of its leaders - until her death. ${ }^{38}$ Although the implication of this transfer of power from mother to son might be that a woman should not rule if there is a legitimate and morally upright male heir, her case makes clear that a woman has a right to rule when a male king proves to be immoral and incompetent.

Most striking, however, is Geoffrey's choice not to villainize this female regent even when she displays extreme anger and orders two killings. Although angered by Locrinus's misdeeds, Guendoloena's label of indignans denotes not only that she is "furious, raging" but also that she is "full of righteous anger". 39 Even the rage that motivates her killing of Estrildis and her daughter Habren does not become grounds for villainization, for this rage is paterna, "paternal", and receives the same lack of criticism that her father Corineus's anger does. ${ }^{40}$ Furthermore, Geoffrey's phrasing presents the deaths of these two women as executions, not murders: Guendoloena [i]ubet, "orders", that they be thrown into the river. ${ }^{41}$ This verb makes the two deaths the result of a ruler's order, an order that preserves both the Britons' ethnic purity and their sovereignty

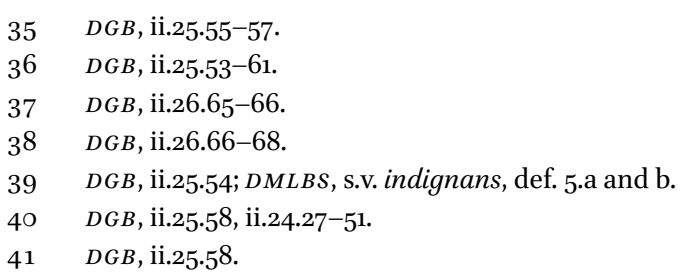


over the island of Britain. The fact that Guendoloena's execution of Habren is not a shameful moral wrong becomes even more evident when Guendoloena proclaims per totam Britanniam, "through all Britain", that the river should be called by this young woman's name. ${ }^{42} \mathrm{By}$ granting to Habren the honorem aeternitatis, "honor of immortality", Guendoloena not only honors Habren's royal blood but also shifts readers' attention away from the execution itself and onto the river as a memorial for the young woman. ${ }^{43}$ Geoffrey's first female ruler turns out to be a regent, but she is a defender of British civilization - not a villain.

In contrast to Geoffrey's circuitous presentation of Guendoloena (the seeming king who turns out to be a regent), his presentation of his first female king, Cordeilla, is straightforward: she is the worthy heir to her father's throne whose reign gains legitimacy through Geoffrey's narratorial condemnation of her nephews as barbarous specifically because they rebel against her due to her gender. Cordeilla proves herself worthy to be king when she displays moral integrity as she tries to save her father from the consequences of his poor decision-making by hinting that her sisters love his possessions rather than him. ${ }^{44}$ She proves her worthiness again when she displays compassion and political savvy as she protects her exiled and bedraggled father from humiliation at the French court, and then works with her husband to grant Leir sovereignty over France until they can help him regain the British throne. ${ }^{45}$ This loyal daughter accompanies Leir, perhaps as an advisor, on the military campaign against his rebellious sons-in-law that puts him back on the throne. ${ }^{46}$ Crucially, Cordeilla reigns as a feme sole (a woman exercising power without a male guardian), for both her husband and father are dead when she accedes to the throne. ${ }^{47}$ In addition, her peaceful five-year reign in a book full of civil wars provides evidence of competence..$^{48}$ Although her nephews' rebellion ends her reign, it reaffirms her right to rule because Geoffrey labels as saeuiciae, "savagery, barbarity", their motive for it: "they were indignant that Britain should be subject to the rule of a woman." ${ }^{\prime 9}$ The nephews' barbarity becomes evident when, after Cordeilla brings five years of peace, they destroy provinces within

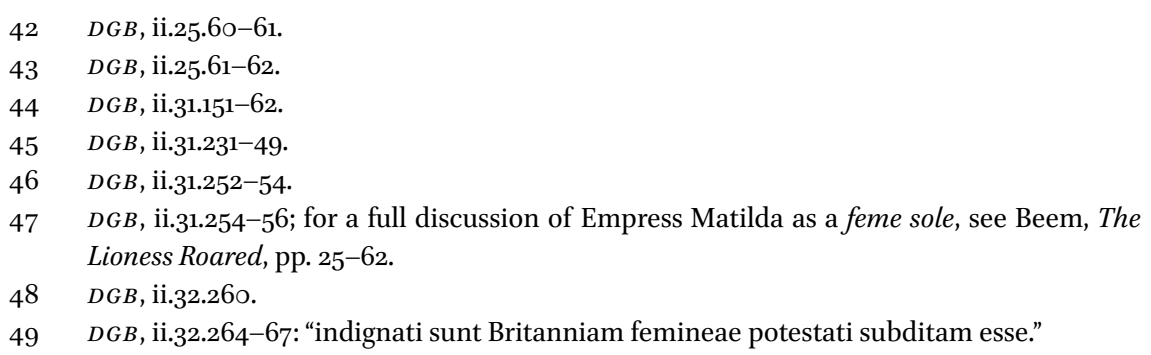


their aunt's kingdom and then battle each other in a violent civil war. ${ }^{50}$ By stating that "on account of being overwhelmed by grief after her loss of royal power, she killed herself", Geoffrey reveals that Cordeilla's personal investment in her identity as a female king is so great that she refuses to live when she can no longer wield political power. ${ }^{51}$ Therefore, he naturalizes the exercise of political power by a woman and implies the necessity and morality of supporting a legitimate female ruler over an incompetent or immoral male.

Marcia, Geoffrey's second female king, not only proves herself to be intellectually superior to her husband and morally superior to her son, but also reigns until she dies. Geoffrey's narration favors Marcia over her husband, King Guithelinus, for the king receives the briefest of mentions as reigning benigne et modeste, "benevolently and with moderation", until his death. ${ }^{52}$ In contrast, Marcia receives praise for possessing the traits that make her intellectually superior to her husband: she is learned in all arts, and she creates not only the law code called the Merchenelage but also "many and incredible things that she invented through her own natural genius". ${ }^{53}$ After Marcia functions as her husband's partner in power who devises a law code, the British crown passes to her and her seven-year-old son, Sisillius. ${ }^{54}$ Nevertheless, Marcia rules as a king rather than a regent, for Sisillius does not become king until after his mother "from this light had departed".55 Geoffrey's narration suggests that, because of Marcia's consilio, "wisdom", and sensu, "moral sense", she "obtained rule over the entire island"; therefore, there is no reason for her son to govern the land until his wise mother can no longer do so. ${ }^{56}$ Because all Geoffrey says about Sisillius is that he "took possession of the crown, assuming control of the government", Marcia apparently surpasses her son in moral sense just as she surpasses her husband in intellectual achievement. ${ }^{57}$

Within Geoffrey's metanarrative of kingship, female rule becomes an attractive alternative to male rule because some male monarchs are weak and foolish while others commit crimes of tyranny, warmongering, sexual misconduct, and/or murder. Guendoloena's successful 15-year reign that makes possible her son Maddan's peaceful 40-year one contrasts strongly with her husband's weak and foolish pursuit of private desire, desire that threatens the legitimate royal

\footnotetext{
5 O $\quad D G B$, ii.32.26o-82.

$5^{1} \quad D G B$, ii.32.269-70: "ob amissionem regni dolore obducta sese interfecit."

$52 \quad D G B$, iii.47.257.

$53 \quad D G B$, iii.47.257-61: "multa et inaudita quae proprio ingenio reppererat."

$54 \quad D G B$, iii.47.259-62.

$55 D G B$, iii.47.265-66: "ab hac luce migrasset."

$56 \quad D G B$, iii.47.264-65: "imperium totius insulae optinuit."

$57 \quad D G B$, iii.47.265-66: "sumpto diademate gubernaculo potitus est."
} 
bloodline and undermines political stability. ${ }^{58}$ It also contrasts strongly with the reign of her tyrannical successor Mempricius: he murders his own brother to obtain the throne, murders family members who might succeed him, and commits sodomy. ${ }^{59}$ Geoffrey's report that a pack of wolves eats Mempricius underscores this tyrant's ravenous appetite for both power and illicit sex. ${ }^{60}$ Cordeilla's predecessors highlight two of her roles: model of competent and peaceful rule, and corrector of male incompetence. First King Leil grows politically weak and neglects his duties, causing civil war to break out; then her father foolishly divides his kingdom and thereby enables his sons-in-law and two dishonest daughters to strip him of power. ${ }^{61}$ Cordeilla's successors likewise make female rule attractive, for her nephews Marganus and Cunedagius fight a civil war, and then the brothers Ferreux and Porrex fight a civil war that triggers a chaotic period during which five kings vie for power. ${ }^{62}$ In Marcia's case, although her predecessors Belinus and Gurguint Barbtruc establish political order, and her husband Guithelinus reigns benignly, her successors make her example of wise kingship shine more brightly. Her reign seems more impressive given that the reigns of her immediate successors (Sisillius II, Kimarus, and Danius) receive no commentary at all, while several of her later successors commit terrible crimes. ${ }^{63}$ For example, Morvidus is a tyrant so bloodthirsty that, after he exhausts himself trying to kill every one of his Flemish enemies, he orders that the remainder be "flayed alive and, after they were flayed, burnt"; because of "these and other barbarous deeds", a monster swallows him. ${ }^{64}$ Later, King Arthgallo loses the British throne for five years because he tries to take for himself all of his people's wealth and strives to remove nobles from their rightful positions, and then King Enniaunus is so tyrannical that he gets deposed. ${ }^{65}$ Although there are good male kings as well as bad, all three of Geoffrey's female rulers are both competent and on the side of right - offering to readers an attractive alternative to rule by males.

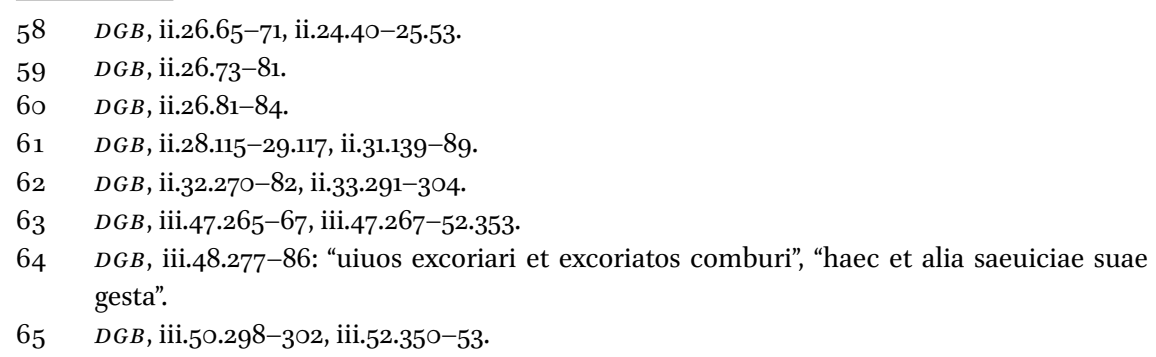


Although literary critics have branded Geoffrey of Monmouth the first medieval author to villainize and marginalize Arthur's queen, Ganhumara, Geoffrey's history actually presents a "feminist" version of the Arthurian past. ${ }^{66}$ Geoffrey's flexible conception of gender roles and empowerment of female figures are evident in his portrayal of the marriage of Uther and Igerna, Merlin's prophecy about Arthur and Anna, and the marriage of Arthur and Ganhumara.

Despite the fact that Uther's acquisition of Igerna through military conquest could have resulted in a loveless marriage of political necessity, Geoffrey makes their marriage a model royal union in which the king and queen are partners in love and perhaps in power too. ${ }^{67}$ They offer proof of their love (and, according to medieval lore, of Igerna's experiencing pleasure in the royal bed) by producing children, a daughter as well as a son: "From then on, they remained together, equally united by no small love, and they begot a son [Arthur] and a daughter [Anna]." 68 Although the translation just offered reflects a traditional interpretation of Geoffrey's sentence, it does so because it assumes that Igerna in particular, and medieval women in general, cannot be in power. Nevertheless, because the word pariter can mean "as equals" only in reference to feudal tenure, a resistant, feminist interpretation of this sentence is possible - one that assumes that Igerna could wield power: "From then on, they remained constantly as equals, with no small love uniting them, and they begot a son [Arthur] and a daughter [Anna]." This nontraditional interpretation is plausible given that the ideals of genuine affection and partnership in marriage appear elsewhere in Geoffrey's history. Britain's first king, Brutus, expresses affection for his homesick bride Innogin by catching her inter brachia, "in [his] arms", and using both dulces amplexus, "gentle embraces", and dulcia basia, "gentle kisses", to calm and comfort her until - exhausted with weeping she falls asleep. ${ }^{69}$ Aganippus not only desires his future wife Cordeilla passionately, despite her lack of dowry, but also functions as her partner in power after they marry: they work together to restore King Leir to the throne using their financial and military resources..$^{70}$ Within this narrative context, it is possible

\footnotetext{
66 L.J. Walters, "Introduction", in ead. (ed.), Lancelot and Guinevere: A Casebook (Arthurian Characters and Themes, 4), New York, 1996, pp. xiii-lxxx, at p. xv; S. Samples, "Guinevere: A Re-Appraisal”, in Walters (ed.), Lancelot and Guinevere, pp. 219-28, at pp. 219-20.

$67 \quad D G B$, viii.138.532-36.

$68 D G B$, viii.138.535-36: "Commanserunt deinde pariter non minimo amore ligati progenueruntque filium et filiam."

$69 \quad D G B$, i. $15.270-16.275$.

$70 \quad D G B$, ii.31.175-85, ii.31.237-54.
} 
that the Uther-Igerna relationship - the only marital relationship that Geoffrey describes explicitly - offers a "feminist" model of a royal marriage, one that makes man and wife partners in both love and power.

Although Geoffrey's redactors and translators altered his "feminist" version of the Arthurian past, Geoffrey presents the children of Uther and Igerna as an expression of the equality - of love and perhaps of power - within their parents' royal marriage.$^{71}$ Merlin asserts that the son will be potentissimum, "most powerful", but the daughter's line will triumph over the son's, for her "sons and grandsons will possess the realm of Britain in succession". ${ }^{72}$ The claim that Arthur will build a vast empire, yet Anna's descendants will reign over Britain, is consistent with the reigns of both the two female kings who succeed a father or husband and the three male kings who either inherit or acquire the throne through the matriline. ${ }^{73}$

Both Arthurian society as a whole and Arthur's court reflect the Galfridian ideas of females being active participants in society and male-female partnerships benefitting society. When Arthur rebuilds British churches that the Saxons have razed, he ensures that both female and male members of the Christian monastic community can return to their holy work; therefore, females are active participants in Arthurian society. ${ }^{74}$ Within the royal court, noblewomen not only share a symbolic identity with their male partners through wearing clothing of the same color as the men's livery and arms, but also participate in a mutual moral improvement program, one that benefits both genders. ${ }^{75}$ While the ladies' love stirs knights in furiales amores, "into frenzied passions", yet inspires them to be probiores, "more honest", the knights' love makes the women both castae, "chaste", and meliores, "more virtuous". ${ }^{76}$ Geoffrey's use of the verb [e]fficiebantur, "they were made" - with the men and women as its joint subject - signals this mutual moral improvement. ${ }^{77}$ At Arthur's court, women are active and visible members of the chivalric community: they are

71 Tolhurst, Feminist Origins, pp. 25-26, $55^{-112 .}$

$72 \quad D G B$, viii.133.369-72: "filii et nepotes regnum Britanniae succedenter habebunt."

73 The two female kings appear in $D G B$, ii.31.254-ii.32.270 (Cordeilla) and iii.47.261-66 (Marcia). One male king inherits the British throne through the matriline in $D G B$, v.74.3237 (Bassianus), while two male kings legitimize their reigns through marrying a female king-candidate in $D G B$, v.78.136-43 (Constantius marries Helena, daughter of Coel) and v.83.291-95 (Maximianus marries Octavius's daughter).

$74 \quad D G B$, ix.151.198-99.

$75 \quad D G B$, ix.157.387-89.

$76 \quad D G B$, ix.157.390-95.

$77 D G B$, ix.157.385-91; S. Echard notes how Geoffrey's "emphasis on the role of women in inciting knightly behaviour foreshadows the preoccupations of the vernacular romances" in "Geoffrey of Monmouth", in ead. (ed.), The Arthur of Medieval Latin Literature: The 
not rewards for knightly valor who function as tokens of exchange between males. Women judge the value of knights, rewarding with their love only those who prove themselves tercio in milicia, "three times in battle". ${ }^{78}$ These passionate partnerships of knights and their ladies link Arthur's court to that of his father Uther, who wooed his future wife Igerna with passion. ${ }^{79}$

The content of Ganhumara's initial description encourages readers to expect that she will wield significant power: she is of Roman lineage, has been brought up in Cornwall, and possesses great beauty - beauty that Geoffrey describes using phrasing nearly identical to that with which he describes Igerna's. ${ }^{80}$ Because the Romans are the standard by which Geoffrey measures British civilization and power, marrying a woman of Roman descent unites two bloodlines (Roman and British) that, in the $D G B$, share a common Trojan origin. ${ }^{81}$ Significantly, Ganhumara's Romanness likens her to Empress Matilda who "began to share the emperor's throne and public life" when she married Emperor Henry v at the age of 11; "undertook the formal duties of government", until her widowhood at the age of 23 , in a German empire that its leaders saw as the heir of the ancient Roman empire; and then retained her title as a consecrated empress until her death. ${ }^{82}$ Ganhumara's upbringing by Cador, duke of Cornwall, suggests both a virtuous nature and the potential to wield power, for Cornwall is the region that produces many outstanding individuals who aid or rule Britain. ${ }^{83}$ Finally, by likening Ganhumara to Igerna through the phrase "she surpassed the women of the island with respect to beauty", Geoffrey sets the expectation that Ganhumara's relationship with Arthur will resemble that of Igerna and Uther. ${ }^{84}$

\footnotetext{
Development and Dissemination of the Arthurian Legend in Medieval Latin (Arthurian Literature in the Middle Ages, 6), Cardiff, 2011, pp. 45-66, at p. 56.

$78 \quad D G B$, ix.157.389-9o.

$79 \quad D G B$, viii.137.454-6o.

8 o $\quad D G B$, ix.152.208-11, viii.137.455-56.

$81 \quad D G B$, iiii.54.6-15.

82 M. Chibnall, The Empress Matilda: Queen Consort, Queen Mother and Lady of the English, Oxford and Cambridge, MA, 1991, pp. 26, 33, 42; Beem, The Lioness Roared, pp. 35, 40.

83 J.S.P. Tatlock notes the pattern of Cornwall and its eponym supplying Britain with both helpers and rulers in Tatlock, $L H B$, pp. 400-o1; $D G B$, i.17.330-i.21.489 (Corineus, eponym of Cornwall); ii.25.52-ii.26.68 (Guendoloena, daughter of Corineus); ii.34.305-37 (King Dunuallo Molmutius); iiii.64.267-71 (King Tenuantius); v.76.68-v.78.124 (King Asclepiodotus); v.87.366-v.88.395 (Duke [called King] Dionotus and his daughter); viii.124.138-49 (Duke Gorlois); ix.143.28-31, ix.148.133-47, x.171.338-42 (Duke Cador); xi.178.81-84 (King Constantinus III); xi.189.210-17 (Duke Bledericus).

$84 D G B$, ix.152.210-11, viii.137.455-56: "tocius insulae mulieres pulcritudine superabat."
} 
Ganhumara fulfills this expectation by wielding both ceremonial and political power at the moment J.S.P. Tatlock calls "the structural and the dramatic climax of the entire Historia". ${ }^{85}$ Her ceremonial power is evident during the crown-wearing at Caerleon, during which Geoffrey presents her as Arthur's partner in power through parallel processions, Masses, and feasts. The parallel processions display, to the nobles present, the political power of both royals; these ceremonies also suggest that the queen rules with the king. The king gets crowned, and then is escorted to a church by four archbishops - with four kings carrying golden swords and an assembly of clergy preceding him. ${ }^{86}$ Ganhumara dons her regalia before she receives escort from archbishops and bishops; the four queens of the aforementioned kings - carrying doves - precede her, and all the women in attendance follow her. ${ }^{87}$ Although the Masses occur in separate churches, they are equally impressive events, for the magnificent music and singing in both locations so enthrall the knights that "they did not know which of the churches they should seek first." 88 The knights' indecisiveness could be Geoffrey's fictionalized version of the Anglo-Norman barons' struggle to choose between the factions of Empress Matilda and King Stephen. At the parallel feasts, the greater number of the queen's attendants maintains the dignity of her feast, despite her husband's servants having expensive matching liveries. ${ }^{89}$ Because the feast sequence segues into Geoffrey's description of the aforementioned mutual moral improvement program at Arthur's court, readers are likely to interpret the queen's celebration as rivaling the king's. Furthermore, Anglo-Norman readers who noticed that Arthur uses his marriage to confirm his status as the ruler of a newly forged European empire and raise himself to a Roman level of greatness might well have associated this celebratory plot sequence with King Henry I's use of his daughter's marriage to Emperor Henry v to confirm his own political status and access to Roman greatness. ${ }^{90}$ Geoffrey confirms that Ganhumara wields political power when Arthur, before leaving Britain to fight the Romans, makes her co-regent with Mordred. Geoffrey's phrasing - "entrusting Britain to his nephew Mordred and to Queen Ganhumara to take care of" - presents the queen as her husband's partner in power. ${ }^{91}$

\footnotetext{
85 Tatlock, $L H B$, p. 270.

$86 \quad D G B$, ix.157.359-64.

$87 \quad D G B$, ix.157.364-68.

$88 \quad D G B$, ix.157.369-71: "nescirent quod templorum prius peterent."

$89 \quad D G B$, ix.157.375-84.

90 Chibnall, The Empress Matilda, p. 16.

$91 \quad D G B$, X.164.14-15: "Modredo nepoti suo atque Ganhumarae reginae Britanniam ad conseruandam permittens".
} 
The "feminist" nature of Geoffrey's version of the Arthurian world becomes even more evident when he condemns Mordred as the primary - and possibly the only - villain in his account of Arthur's loss of power. Ganhumara becomes a possible victim of circumstance for two reasons. One is that her status as co-regent disappears at the moment of betrayal, a detail that mitigates her responsibility for Arthur's downfall..$^{92}$ The other is that Geoffrey presents her one moral wrong, violating her marriage vows, using phrasing that makes her a grammatical object: she "had been joined to the same man [Mordred] in abominable sexual relations". ${ }^{93}$ The passive verb form copulatam fuisse represents her misdeed indirectly. This choice of phrasing on Geoffrey's part can be read in both a traditional way and a resistant, feminist one. A traditional interpretation of this passage would assert that the passive verb form does not lessen the gravity of Ganhumara's offence, and therefore brands her as the root of "the negative portrayal of Guinevere, which would come to color the [Arthurian] tradition". ${ }^{94}$ However, a resistant reading would assert that this passive form makes the queen seem less than fully responsible for her sexual relationship with her nephew, a detail consistent with the possibility that Mordred rebelled and gathered a large army to support his claim to the throne, and then gave the queen little choice but to accept his sexual advances. This possibility becomes more likely when Geoffrey's phrasing brands Mordred the villain who "had usurped [Arthur's] crown through tyranny and treachery" as well as the only traitor in this episode: Mordred is the person "into whose safekeeping [Arthur] had entrusted Britain". ${ }^{95}$ Geoffrey further underscores the nephew's violation of his uncle's sovereignty and marital bed by breaking the narrative frame at this point to assert that he will not remain silent about this event. ${ }^{96}$ This act of narratorial slow motion might well have caused Anglo-Norman readers to recall Stephen of Blois's decision to betray his uncle Henry I by usurping the

$92 \quad D G B, \mathrm{X} .176 .48 \mathrm{O}-84$.

$93 \quad D G B, \mathrm{X} .176 .483-84$ : "nefanda uenere copulatam fuisse." Wright translates copulatam fuisse as a deponent verb, so Ganhumara "united" with Mordred (DGB, x.176.484). However, I follow Fries in interpreting the verb form as passive and build upon her observation that "the passive verb makes the Queen's cooperation with the usurper [Mordred] problematic"; M. Fries, "Gender and the Grail", Arthuriana 8:1 (1998), 67-79, at p. 69. Given that in the seven other situations in which Geoffrey uses the verb copulare, not once does he use the verb as a deponent, interpreting copulatam fuisse as a passive form is the option most consistent with the author's pattern of usage. See $D G B$, ii.24.27; ii.31.141; ii.31.177; iii.40.105; iiii.68.330 (I interpret this form as passive); v.81.201; and v.81.225.

94 Walters, "Introduction", in ead. (ed.), Lancelot and Guinevere, p. xv.

$95 D G B$, x.176.481-83: "eiusdem diademate per tirannidem et proditionem insignitum esse", "cuius tutelae permiserat Britanniam."

$96 \quad D G B, x i .177 \cdot 1-5$. 
throne the king had left to his daughter Empress Matilda. The possibility that Ganhumara is her nephew's victim rather than his co-conspirator becomes even more likely when Geoffrey labels Mordred sceleratissimus proditor ille, "that most criminal traitor" - a superlative adjective he has already applied to the murderous Giant of Mont-Saint-Michel - and the queen as desperans, "despairing", as she flees to a convent after hearing that her nephew is approaching Winchester. ${ }^{97}$ Mordred's epithet $[p]$ eriurus, "the perjurer", makes readers wonder whether the queen flees at the thought of Mordred gaining permanent possession of both her and the kingdom. ${ }^{98}$

Ganhumara is striking because she is complex in her characterization: she is a powerful queen who breaks her marriage vows and fails to produce an heir. However, what distinguishes her from the versions of Arthur's queen that Geoffrey's translators and other successors created is that she is a female figure whom Geoffrey chooses not to villainize, despite her committing the moral wrong of adultery that (because her spouse is King Arthur) constitutes treason. ${ }^{99}$ Furthermore, Ganhumara's case reveals that Geoffrey does not blame female figures' moral failings on supposed feminine weakness. In addition, he tends to create portraits of female moral strength, dignity, and heroism.

Both Helena, the niece of Hoelus, and Helena's nursemaid suffer acts of violence perpetrated by the Giant of Mont-Saint-Michel; nevertheless, Geoffrey assigns to each of these female figures a brand of heroism that proves her moral strength and gives her dignity despite her victimization. In contrast to Arthur who displays traditional male heroism when he kills the giant with a skull-splitting sword stroke, the nursemaid displays knightly heroism. ${ }^{100}$ At first she seems to be a victim, for she enters the narrative as "an old woman crying and wailing" and expresses to Beduerus her feelings of pain and sorrow in response to the giant's crimes: kidnapping both her and Helena, attempting to rape Helena, and raping her. ${ }^{101}$ However, the nursemaid soon proves her moral strength by taking on a knightly function, for she not only risks dismemberment by the giant as much as Arthur or Beduerus does but also takes on the role of the knightly hero by protecting Beduerus from a terrible fate. The nursemaid tries to prevent Beduerus's "death of indescribable sufferings" by advising him to flee before the giant can tear his body to pieces "in miserable

$97 \quad D G B$, xi.177.10, X.165.58, xi.177.33-34.

$98 \quad D G B, x i .177 \cdot 3^{2}-35$.

99 Tolhurst, Feminist Origins, pp. 55-112.

$100 \quad D G B, \mathrm{x} .165 .90-91$.

$101 \quad D G B$, X.165.52, X.165.55-67: "anum flentem et eiulantem". 
massacre", then consume him while he is in "the flower of [his] youth". ${ }^{102}$ In this interaction, she functions as a knight, for she protects someone whom she describes using imagery often associated with female virgins. The nursemaid's humble and willing sacrifice to protect one of Arthur's men constitutes an alternative to the brutal and selfish heroism of the king and gives her dignity even as she reports the violation she has suffered. ${ }^{103}$ Helena's brand of heroism defeats the Giant of Mont-Saint-Michel through an act of will despite her fear: she denies him the prize of her virginity as a virgin martyr-saint would. Like Dionotus's daughter and her female companions, who experience great fear at the hands of barbarians but choose death over sexual violation, Helena suffers timore, "fear", when the giant embraces her; nevertheless, she dies before he can sexually violate her - and precisely because she fears being violated by such a creature. ${ }^{104}$ Helena's apparent inability to accept the possibility of losing her virginity through an act of violence makes her a model of moral strength, a secularized version of the medieval virgin martyr-saint. Geoffrey celebrates Helena's brand of heroism by inventing the etymology for the place he calls Helena's Tomb, the site of her burial. ${ }^{105}$ In this way, her heroism becomes part of the landscape of Normandy.

Geoffrey of Monmouth claims in the opening line of his $V M$, composed c.115o, that this poem will focus on "the madness of the prophetic seer", yet the prominent and varied roles of its female figures reveal a different focus: female power. ${ }^{106} \mathrm{Here}$, as in the $P M$ and the $D G B$, Geoffrey depicts female figures in mostly positive ways while assigning to them both male and female roles. Strikingly, the only major character whom Geoffrey adds to the Arthurian material he reworks in this poem is Morgen, a sorceress and ruler. ${ }^{107}$ Furthermore,

\footnotetext{
$102 D G B$, x.165.55-57, x.165.66-67: "inenarrabiles mortis poenas", "miserabili caede", "florem iuuentutis".

103 J.J. Cohen, "Decapitation and Coming of Age: Constructing Masculinity and the Monstrous", The Arthurian Yearbook 3 (1993), 173-92, at p. 179, citing M. Kundera, "The Traffic in Women: Notes on the 'Political Economy' of Sex", in R.R. Reiter (ed.), Toward an Anthropology of Women, New York, 1975, pp. 157-210.

$104 \quad D G B$, v.88.373-95, X.165.61-66.

105 L. Thorpe, "Le Mont Saint-Michel et Geoffroi de Monmouth", in R. Foreville (ed.), Vie montoise et rayonnement intellectuel du Mont Saint-Michel (Millénaire monastique du Mont Saint-Michel, 2), Paris, 1967, pp. 377-82, at pp. 380-82.

$106 V M$, l. 1: "[f]atidici vatis rabiem".

107 B. Clarke notes this fact in the introduction to the $V M$, pp. vii-5o, at p. 4.
} 
Geoffrey invents the figure of Merlin's wife Guendoloena and transforms the figure of Merlin's sister into her brother's rival, one who eventually succeeds to Merlin's position as prophet of the Britons and Geoffrey's position as author. ${ }^{108}$

Like Geoffrey's history, his Arthurian poem both critiques the princely power that, through military action, has devastated cities full of civilians and celebrates female power in gender-bending ways. ${ }^{109}$ The figure now known as Morgan le Fay enters the Arthurian literary tradition as one of nine sisters who enforce a geniali lege, "friendly law", upon visitors to Avalon, although Morgen surpasses her siblings in both beauty and skill in healing. ${ }^{110}$ As Fries has noted, Geoffrey's introduction of Morgen and the land she rules in "positive and even ... androgynous" terms, as well as his presentation of her as ruling without "a male consort", contrasts sharply with Morgen's later incarnation - the "tramp": a sexually active, then incestuous, and finally rather pathetic figure who (lacking magical powers of her own) uses magical skills to entrap men in order to satisfy her lust. ${ }^{111}$ Within the context of medieval authors' erosion of both her powers and her goodness, Geoffrey's Morgen is a standout. She bends the rules of traditional gender roles in part because she is a sorceress, yet her magical powers of shapeshifting and flying are presented matter-offactly - not with the moral ambiguity that antifeminist authors tend to assign to sorceresses. ${ }^{112}$ Morgen also bends these rules by teaching mathematicam, "mathematics, astrology" (a scientific field traditionally dominated by males)

108 B. Clarke states in his name notes index to the $V M$ that "Guendoloena, Merlin's wife, is a new character without direct antecedents"; $V M$, pp. 156-226, "Guendoloena", at p. 186. N. Tolstoy agrees with Clarke that "There can be no doubt that Geoffrey invented the character of Guendoloena" in "Geoffrey of Monmouth and the Merlin Legend", $A L 25$ (2008), $1-42$, at p. 37 .

$109 V M$, ll. 23-25.

$110 V M$, ll. 916, 918-19.

111 M. Fries, "From The Lady to The Tramp: The Decline of Morgan le Fay in Medieval Romance", Arthuriana 4:1 (1994), 1-18, at p. 2. Fries, at pp. 3-5, traces this decline: Chrétien de Troyes' Erec and Enide assigns Morgan her first lover, Guiomar; 13th-century French prose romances transform this affair into the incestuous and shameful cause of her exile from Arthur's court as well as her motivation for exploiting Merlin's love for her to gain knowledge of enchantment; later French romances transform her into an evil sorceress who tries to entrap Guiomar and other lovers, thereby fulfilling her sexual desire and destroying them, yet must now learn magic from a male; the Prose Merlin presents her as attending a convent school; Hartmann von Aue reduces her to the supplier of a healing plaster for Erec's wounds; and then the Prose Lancelot, Prose Tristan, and Thomas Malory's Morte D'Arthur reduce the means of her sorcery to drugging wine or using a "magic potion or powder".

112 VM, ll. 920-25; S. Echard, Arthurian Narrative in the Latin Tradition (Cambridge Studies in Medieval Literature, 36 ), Cambridge, 1998, p. 153. 
to her sisters. ${ }^{113}$ Morgen's androgyny is evident in the combination of roles she plays: the safely feminine ones of fertility goddess, healer, and beauty, and the traditionally masculine ones of teacher of mathematics and/or astrology and ruler. ${ }^{114}$ Morgen's place of residence supports Geoffrey's positive presentation of her power. "The Fortunate Island" (Island of Apples), which Michael J. Curley identifies as "a variation on the topos of a lost paradise or Golden Age" present in both Ovid's Metamorphoses and Celtic mythology, is a female-run second Eden. ${ }^{115}$ This paradise not only replaces the Edenic island of Britain idealized at the beginning of the $D G B$ but also provides a model of feminine stability and peace - one that contrasts with the political instability and civil wars that fill Geoffrey's history of early Britain. ${ }^{116}$

Geoffrey's Morgen takes on greater significance both because her powers surpass those of Merlin (normally the dominant magical figure in Arthurian literature), and because she contributes to a pro-female pattern at work in the poem. In Geoffrey's history, Merlin possesses both engineering skill and the gift of prophecy; in his Arthurian poem, Merlin still possesses the gift of prophecy, despite going mad in response to the terrible loss of life caused by a civil war. ${ }^{117}$ Nevertheless, Morgen surpasses Merlin when she resolves the situation with which the Arthurian section of the $D G B$ ends: the mortally wounded King Arthur gets carried to the island of Avalon for healing. ${ }^{118}$ She, unlike her male counterpart, has the power to heal the king's mortal wound. ${ }^{119}$ After Morgen declares that she can cure Arthur only if he remains under her care for a long time, the $V M$ explains that the Britons leave her presence rejoicing - apparently confident that she will heal their king. ${ }^{120}$ Geoffrey's artistic choice of creating this connection between Morgen and the mortally wounded king constitutes part of a pro-female pattern at work in the poem: Morgen heals Arthur of a physical wound, and Ganieda heals Merlin of a psychological wound. ${ }^{121}$

\footnotetext{
$113 V M$, ll. 926-28.

$114 V M$, ll. 9o8-28.

115 M.J. Curley, Geoffrey of Monmouth (Twayne's English Authors Series, 509), New York, 1994, p. $126 ; V M$, ll. $908-17$.

$116 D G B$, i.5.24-38.

$117 D G B$, viii.128.212-130.279, vii.111.25-117.304, viii.133.355-72; VM, ll. 1-2, 19-76.

$118 D G B, x i .178 .81-84$.

$119 V M$, ll. 929-38.

$120 V M$, ll. $936-40$.

121 For Geoffrey of Monmouth's invention of Morgen's link with the wounded Arthur, see Clarke's name notes index to the $V M$, "Morgen”, VM, p. 203 and A.O.H. Jarman, "The Merlin Legend and the Welsh Tradition of Prophecy", in R. Bromwich, A.O.H. Jarman, and B.F. Roberts (eds.), The Arthur of the Welsh: The Arthurian Legend in Medieval Welsh Literature (Arthurian Literature in the Middle Ages, 1), Cardiff, 1991, pp. 117-45, at p. 133. For Ganieda's healing of Merlin, see VM, ll. 165-209.
} 
Both Geoffrey's invention of a wife for Merlin and his choice of having her contribute to the poem's dramatic intensity show that he deliberately included prominent female figures in his works throughout his career; however, Guendoloena's displacement and dismissal reveal Geoffrey's favoring of female figures who play nontraditional gender roles. Because Guendoloena asserts an emotional claim on her husband that competes with Ganieda's claim, this traditional wife-figure contributes to the poem's dramatic intensity: "They doubled the force of their kisses in competition with each other and, moved by great tenderness, wrapped their arms around the man's neck."122 Nevertheless, Geoffrey not only gives Guendoloena less narrative space than Ganieda but also signals his higher level of interest in nontraditional females by displacing, and then dismissing, this figure whom Basil Clarke describes as a "faithful tearful dependant". ${ }^{123}$ Ganieda proves herself to be the dominant female figure of the $V M$ even before her sister-in-law collapses under the weight of unbearable grief, grief due to Merlin's harsh rejection of her: Ganieda does so by bringing Merlin's behavior back into conformity with courtly norms and by restoring him to sanity. ${ }^{124}$ In addition, she displaces Guendoloena by speaking for her - articulating Guendoloena's desire to go with Merlin as well as asking him whether Guendoloena has his permission to remarry. ${ }^{125}$ Merlin's words and actions, however, dismiss Guendoloena. Although Ganieda sends for her sisterin-law so that she can help Ganieda prevent Merlin's departure for the woods, Guendoloena's pleas neither change Merlin's plans nor receive his usual kindly look. ${ }^{26}$ Crucially, Merlin's strongest emotion during this interchange with the two women is distaste for his wife. He implies that his wife's weeping repulses him when he says, "I do not want, sister, a sheep that pours out water in a spring's gaping cleft that is as wide-open as the Virgin's Urn during flood."127 Both by characterizing his wife as a (presumably dull-witted) sheep and by using the word hiatus, "space (between parts)" or "cleft", a word that can have off-color connotations, Merlin expresses distaste. ${ }^{128}$ His comment that he will not become an Orpheus - meaning he would rather leave his wife in Hades than try to rescue her - constitutes implicit rejection of his wife. ${ }^{129}$ His lack of

$122 V M$, ll. 217-18: "Oscula certatim geminant et brachia circum / colla viri flectunt tanta pietate moventur."

123 Clarke, name notes index to the $V M$, "Guendoloena", $V M$, p. 186.

$124 V M$, ll. $357-61,122-26,165^{-212 .}$

$125 V M$, ll. $362-67$.

$126 V M$, ll. 354-59.

$127 V M$, ll. 369-70: "Nolo soror pecudem patulo que fontis hiatu / Diffundit latices ut uirginis urna sub estus."

128 DMLBS, s.v. hiatus, def. 1 and short definition.

$129 V M, 11.371-73$. 
emotional attachment to his wife becomes evident in his willingness to provide a dowry so that Guendoloena can marry whomever she wishes. ${ }^{130}$ Setting Guendoloena aside enables Geoffrey to focus on Ganieda, a character who plays both male and female roles.

Although Clarke has dubbed Ganieda "after Merlin the best-realised character in [the] $V M^{\prime \prime}$, the variety of roles Ganieda plays gives her character a complexity that might make her better realized than Merlin. ${ }^{131}$ When she rescues and restores Merlin, she plays the role of female hero. After learning that her brother has gone mad following the loss of his close companions in a Briton-Scot civil war, Ganieda sends retainers to bring Merlin back to the royal court over which she presides with her husband, King Rodarchus of Cumbria. ${ }^{132}$ Given that Ganieda's messenger returns her brother to sanity using a song about how Merlin's sister and wife mourn for him with equal intensity, Ganieda heals her brother by providing both the physician (the messenger) and the cure (the content of the song). ${ }^{133}$ This song restores the prophet to his true self, for it restores his ability to think rationally and reject his other, mad self whom odit, "he hates" - a self that is "other" because it cannot be "moved by the devotion/ compassion of his sister and wife". 134

Ganieda gains additional complexity because she functions as a female counter-hero, yet Geoffrey does not villainize her. ${ }^{135}$ Even when Geoffrey marks Ganieda as an adulteress through a leaf that got caught in her hair during a sexual encounter with her lover, he neither labels her a villain in this part of the plot sequence, nor makes a disparaging comment about women in general based on the moral wrong she has committed. ${ }^{136}$ Although a reader might explain and excuse her sexual activities by categorizing Ganieda as a "fairy-mistress", Geoffrey's neutral narration is striking - especially given that Merlin's laughing scornfully at his sister and identifying her action as illicit provide an obvious opportunity for misogynistic comments. ${ }^{137}$ More importantly, both Geoffrey and Merlin blame males for the problems at Rodarchus's court. When Merlin relapses into madness after returning to court, Geoffrey could disparage Ganieda for both orchestrating the prophet's return to court

\footnotetext{
13 o VM, ll. $375^{-76,381-84 .}$

131 Clarke, name notes index to the $V M$, "Ganieda", $V M$, p. 184.

$132 V M$, ll. 121-26.

$133 V M, 11.165^{-209 .}$

$134 V M$, ll. 207-11: "motus pietate sororis / uxorisque".

135 Clarke acknowledges Ganieda's complexity, name notes index to the $V M$, "Ganieda", $V M$, p. 184.

$136 V M$, ll. 258-61, 285-93.

137 On Ganieda as fairy-mistress, see L.A. Paton, "Merlin and Ganieda", Modern Language Notes 18:6 (1903), 163-69, at p. 167; VM, ll. 262, 285-93.
} 
and corrupting the court through her immorality. Instead, Geoffrey blames this madness on "such great crowds of people", crowds that must include males. ${ }^{138}$ Merlin then suggests that the materialism of King Rodarchus is the root cause of the court's corruption, for he both rejects the king's attempt to bribe him into remaining at court using clothes, horses, and treasure and associates the king's gifts with corruption; Rodarchus's attempt to cheer Merlin up by sending him to a marketplace only underscores the king's materialism. ${ }^{139}$ Rodarchus seems even more blameworthy when he resorts to chains to restrain the unbribable Merlin, yet Merlin must also shoulder some blame because he is determined to return to the woods and remain a mad, distorted version of his true self. ${ }^{140}$

Geoffrey presents positively even Ganieda's role as trickster, despite her undermining Merlin through this role. Although Rodarchus turns his face from her and curses the day he married her after learning that she has lain outdoors with her lover, Ganieda not only uses her womanly charm to claim her innocence but also tricks her brother into uttering three different prophecies about a single boy by twice disguising the child; consequently, she discredits her furenti, "raving", brother as a witness against her. ${ }^{141}$ Strikingly, Geoffrey expresses admiration for this female trickster who functions here as a counter-hero, saying, "This ingenious woman, as soon as she saw [the boy], immediately formulated an unusual trick by which she could vanquish her brother."142 Her triumph becomes complete when Rodarchus feels vexed that he condempnarat amantem, "condemned his lover", and then Ganieda grants her husband veniam, "pardon", kisses and caresses him, and restores him to letum, "happiness". ${ }^{13}$ Assuming that Geoffrey knew a Lailoken tale in which the queen plots the prophet's murder because he has used the leaf in her hair to reveal her adultery, this joyful resolution of the adultery plot suggests that Geoffrey selectively edited the Merlin tradition to shape his Ganieda into a positive female figure. ${ }^{144}$

When the death of her husband King Rodarchus frees her from earthly concerns, Ganieda appropriates a male role by becoming first a political, and then a Christian, philosopher. In a 35 -line speech, Ganieda articulates her transformation from widow into philosopher. ${ }^{145}$ As she eulogizes her husband,

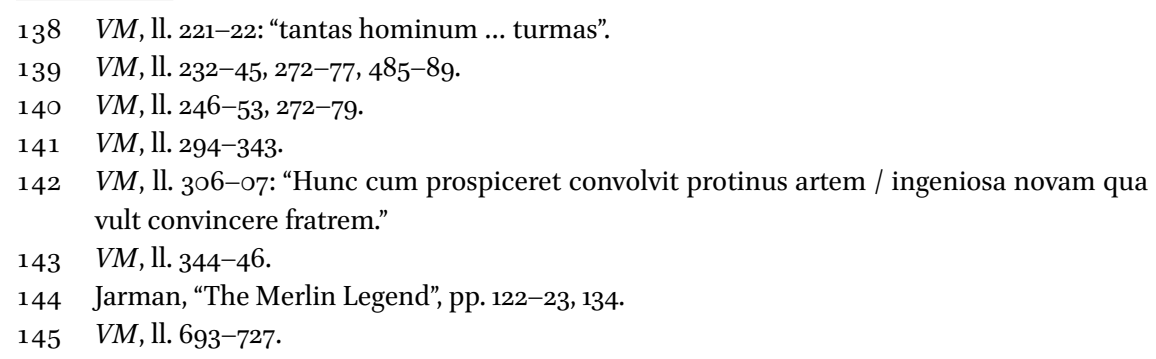


Ganieda expresses the essence of the political philosophy central to Geoffrey's $D G B$ : that a good king loves peace, brings peace between warriors, respects the clergy, gives justice to both the highborn and the lowly, and is generous. ${ }^{146}$ Ganieda states that Rodarchus's body must rot in the ground, and that the glory of the world is fleeting. ${ }^{147}$ By implicitly critiquing her husband's pursuit of worldly power, Ganieda takes on a role like that of the three female rulers in the $D G B$ who correct the foolish and inappropriate behavior of males and enable men to lead better lives; therefore, Geoffrey's Arthurian poem - like his history - can be read as a mirror for princes. As the first character in the $V M$ to mention Jesus Christ, Merlin's sister then articulates the Christian philosophical position that people will gain happiness - and Christ will grant them perpetuo ... honore, "an eternal reward" - if they perstant, "remain steadfast", in both their piety and service to God, and then leave their earthly lives. ${ }^{148}$ After transitioning into her role as philosopher, Ganieda asserts that the primary relationship in her life is the one she has with her brother, and she pledges to live with him, wearing a black cloak and joyfully worshipping God. ${ }^{149}$

When Ganieda succeeds Merlin as prophet of the Britons, Geoffrey shows that his Arthurian poem resembles his history: it presents female power as an attractive alternative to male power. Ganieda starts off as the facilitator of her brother's prophecies. After she provides Merlin with both the space in which to prophesy and the secretaries to record his words, he utters a prophecy that takes the Anglo-Normans to task for fighting a civil war. ${ }^{150}$ Nevertheless, Ganieda has the last prophetic word in the VM. ${ }^{151}$ Geoffrey prepares for Ganieda's replacement of the often-acerbic Merlin by having her join an all-male spiritual fellowship, one that includes both her brother and his companion Telgesinus, but excludes the leaders present at Maeldinus's healing. ${ }^{152}$ Because her prophetic utterance is the only one in the poem about the political landscape of Geoffrey's present and recent past, it has the greatest relevance to Geoffrey's Anglo-Norman audience. Through this prophecy, Ganieda replaces Merlin as prophet, yet her acquisition of her brother's position seems natural: she utters prophecies when she rises ad alta spiritus, "to spiritual heights", possessing an altered state of consciousness like that of both Merlin and the oracles of the ancient world. ${ }^{153}$ It also seems natural because she begins to prophesy

\footnotetext{
$146 \quad V M, 11.693^{-702 .}$

$147 \quad V M$, ll. $703^{-14}$.

$148 V M$, ll. $720-23$.

$149 V M$, ll. $724-27$.

$15^{\circ} V M, 11.555^{-66,654-8 \text { o. }}$

$15^{1} V M$, ll. 1474-1517.

$152 \quad V M$, ll. 1461-65.

$153 V M$, ll. 1469-70.
} 
while standing in her brother's aula - a word with the basic meaning of "hall", but whose additional meanings - "royal ... favour, usage", "hall of justice", and "demesne" - connote aristocratic power, power she is in the process of acquiring from her brother. ${ }^{154}$ Merlin himself declares that his sister has become spiritual royalty when he acknowledges her as the prophetic voice of the Britons, willingly conferring all his power upon her: "Is it you, sister, the breath [of prophecy] has preferred to foretell future things, and closed my mouth and little book? Therefore, this undertaking is given to you. Rejoice in it and assert all things faithfully through my authority."155 Although Ganieda's gift of prophecy stuns her friends into silence, her brother not only congratulates her but also tells her to rejoice in the gift she has received. ${ }^{156}$

This smooth transfer of power reveals that the Merlin-Ganieda relationship frees Ganieda from normative gender roles, for it lacks the tension typical of brother-sister relationships in mythology. Merlin and Ganieda have both Einverständnis, "mutual understanding", and Austauschbarkeit ihrer prophetischen Funktion, "interchangeability of their prophetic function". 157 This relationship between equals liberates the female character to exercise power without being branded an extraordinary woman. Ignoring medieval literary norms, Geoffrey naturalizes the transfer of vaticinal power from a male to a female character; to take a prominent example, Dante Alighieri demonizes the prophet Tiresias whose body changes from male to female and back again. ${ }^{158}$ Geoffrey's flexible approach to gender roles positions him outside of - and in opposition to - the medieval antifeminist tradition.

Geoffrey's willingness to embrace female power becomes all the more evident when he announces the end of his own career as a writer immediately after Merlin announces the end of his career as a prophet. Geoffrey ends his poem with the assertion, "Britons, give a laurel wreath to Geoffrey of Monmouth. He is indeed yours, for at one time he sang of your battles and those of your leaders, and he wrote a little book that today people call The Deeds of the Britons - deeds that are celebrated throughout the world."159 Geoffrey's use of

\footnotetext{
$154 D M L B S$, s.v. aula, def. 1, 3, 4, and 5b.

$155 V M$, ll. 1521-24: "Tene, soror, voluit res precantare futuras / spiritus osque meum compescuit atque libellum? / Ergo tibi labor iste datur. Leteris in illo / auspiciisque meis devote singula dicas."

156 VM, ll. 1518-24.

157 I. Vielhauer-Pfeiffer, "Merlins Schwester: Betrachtungen zu einem keltischen Sagenmotiv", Inklings: Jahrbuch für Literatur und Ästhetik 8 (1990), 161-79, at p. 178.

158 Dante Alighieri, Inferno Canto 20, 1l. 40-45, trans. R. and J. Hollander, Dante. The Inferno, New York, 200o, pp. 362-63.

$159 V M$, ll. 1525-29: "Britanni, / laurea serta date Gaufrido de Monemuta. / Est etenim vester, nam quondam prelia vestra / vestrorumque ducum cecinit scripsitque libellum / quem nunc Gesta vocant Britonum celebrata per orbem."
} 
the verb canere, that denotes both singing and foretelling, allies him with his three characters who sing their prophecies: Telgesinus, Merlin, and Ganieda. ${ }^{160}$ Furthermore, his announcement means that Ganieda is the only prophet and potential author at the end of the $V M$ : she has inherited Merlin's role as the recipient of spiritual wisdom and, as prophet, can continue to sing of the future after Geoffrey withdraws from Anglo-Norman politics. At the end of the $V M$, Ganieda is in charge of receiving spiritual wisdom and disseminating it to the Britons, and her voice finally replaces the voices of both her brother and the author who created her.

The extant works of Geoffrey of Monmouth are examples of medieval "feminism" because they resist the antifeminist tradition in several ways. The $P M$, $D G B$, and $V M$ all assign pivotal roles to female figures and present female figures in predominantly positive ways - even when they are involved in potentially damning situations. As a narrator, Geoffrey consistently chooses not to villainize powerful females, whether they appropriate male roles as Morgen, Ganieda, and his female rulers do, or commit moral wrongs as both Ganhumara and Ganieda do. In addition, he creates a variety of female heroes in characters such as Helena, niece of Hoelus, and her nursemaid, and celebrates the cleverness of a female counter-hero, Ganieda. Even when a female character suffers victimization, he gives her moral strength and dignity. Geoffrey's willingness to use female figures to critique the misconduct of male kings might well be a reaction to King Stephen's usurpation of the English throne and weaknesses as a ruler. Although Geoffrey's history could be dismissed as a piece of propaganda that prepares for the future reign of Empress Matilda as England's first female king, his $V M$ reveals that all of this author's extant works reflect the same tendencies: to allot more narrative space to powerful female figures playing nontraditional roles than to powerless ones playing traditional roles, to empower females to correct male misdeeds, and to present female power as both natural and as an attractive alternative to male tyranny. Geoffrey's consistently "feminist" agenda merits both further study of his works and continued efforts to identify other male authors who resist the medieval antifeminist tradition.

160 DMLBS defines canere as "to sing" and "to recite", but it does not link this verb with the idea of foretelling, s.v. 1 canere v.1 and 5. However, that meaning is present in classical Latin; see The Oxford Latin Dictionary, ed. P.G.W. Clare, Oxford, 1982, s.v. cano, def. 8. Geoffrey's knowledge of classical Latin literature would have made invoking these two meanings of the verb natural to him. 